\title{
Randomly Amplified Polymorphic DNA Markers Linked to Fusarium Wilt Resistance in Diverse Melons
}

\section{X.Y. Zheng ${ }^{1}$ and David W. Wolff ${ }^{2}$ \\ Department of Horticulture Science, Texas Agricultural Experiment Station, Texas A\&M University System, 2415 East Highway 83, Weslaco, TX 78596 \\ Additional index words. Cucumis melo, Fusarium wilt, Fusarium oxysporum, polymerase chain reaction, marker-assisted selection, molecular marker identification and application, genetics, disease}

\begin{abstract}
Three randomly amplified polymorphic DNA (RAPD) markers (E07, G17, and 596) linked to the Fom-2 gene, which confers resistance to race 0 and 1 of Fusarium oxysporum f. sp. melonis, were evaluated by RAPD-polymerase chain reaction for their linkage to Fusarium wilt resistance/susceptibility in diverse melon cultigens (48 resistant, 41 susceptible). Primer 596 was identified in the multiple disease-resistant breeding line MR-1, whereas E07 and G17 were identified in the susceptible 'Vedrantais'. The RAPD markers E07 (1.25 kb) and G17 (1.05 kb) correctly matched phenotypes in $88 \%$ and $81 \%$ of the cultigens. The validity of the RAPD scores was verified by Southern hybridization analysis for sequence homology and bulked segregant analysis of a selected cross population for the linkage. These results will facilitate the introgression of resistance genes into susceptible lines from multiple sources in marker-assisted selection.
\end{abstract}

Fusarium wilt of melon (Cucumis melo L.), a soilborne disease caused by Fusarium oxysporum Schlechtend: Fr. f. sp. melonis W.C. Snyder \& H. N. Hans, was first reported in New York in 1930 (Chupp, 1930a, 1930b). Since then, it has been found in many melongrowing areas worldwide (Leach, 1933; Leach and Currence, 1938; Leary and Wibur, 1976; Quiot et al., 1979; Sherf and Macnab, 1986), with up to $100 \%$ yield losses being recorded (Benoit, 1974; Sherf and Macnab, 1986). Four races have been identified and named $0,1,2$, and 1-2 (Risser, 1973; Risser et al., 1976). In North America, race 2 was essentially the only race known until 1985, when race 1 was isolated in Maryland; in 1996, race 1 was found in California and Ont., Canada (Zitter, 1997). Resistance to races 0 and 1 , and to races 0 and 2 , is controlled by two independent, dominant genes, Fom-2 and Fom-1, respectively (Pitrat,

Received for publication 25 May 1999. Accepted for publication 18 Oct. 1999. This manuscript includes research supported and conducted by the Texas Agricultural Experiment Station, The Texas A\&M Univ. System. We thank Michael Pitrat for providing seeds of resistant melons from the INRA collection and Brian Moraghan (Asgrow Seed Co.) for providing the seeds of the $\mathrm{BC}_{1} \mathrm{~S}_{1}$ families and for the financial support for the project. We also appreciate the editorial assistance of K.E. Hummer, F.G. Dennis, Jr., M.E. Miller, and T.E. Mirkov for making this a better manuscript. The cost of publishing this paper was defrayed in part by the payment of page charges. Under postal regulations, this paper therefore must be hereby marked advertisement solely to indicate this fact.

${ }^{1}$ To whom reprint requests should be addressed. X.Y. Zheng; E-mail address: xi-zheng @ tamu.edu. Fax: (956) 969-5620.

${ }^{2}$ Current address: Sakata Seed America, Inc., P.O. Box 1118, Lehigh Acres, FL 33970-1118.
1991; Risser, 1973; Risser et al., 1976; Robinson et al., 1976; Sherf and Macnab, 1986; Williams et al., 1990; Zink, 1992; Zink and Thomas, 1990). A third gene, Fom-3, controls the resistance to race 0 and 2 in 'Perlita FR' (Zink, 1991; Zink and Gulber, 1985). Planting resistant cultivars is the main strategy for disease control.

Recently, three randomly amplified polymorphic DNA (RAPD) markers (E07, G17, and 596) linked to the Fom-2 gene that confers resistance to race 0 and 1 of $F$. oxysporum have been reported (Baudracco-Arnas and Pitrat, 1996; Wechter et al., 1995). Primers E07 and G17, which produced a $1.25-\mathrm{kb}$ and a $1.05-\mathrm{kb}$ fragment, respectively, were identified in the susceptible line 'Vedrantais'. Primer 596 produced a 1.6-kb fragment and was identified only in the multi-disease-resistant breeding line MR-1. More reliable and easily scored codominant cleaved amplified polymorphic sequences (CAPS) and restricted fragment length polymorphism (RFLP) markers linked to Fom2 gene are available by converting from RAPD markers E07 and G17 (Zheng et al., 1999). However, these RAPD markers remain of interest to melon breeders because of their simplicity, rapidity, and cost-efficiency. Besides, although RAPD markers are generally regarded as useful only within the specific breeding population from which they were identified, the susceptible-linked RAPD primers E07 and G17 showed co-segregation with phenotype in a small sample tested previously (Wolff and Zhou, 1996). Assuming that susceptibility is a primitive allele of the Fom-2 gene, a marker linked to a susceptible allele may be usable over a wider array of genotypes than one linked to a resistant allele. This hypothesis can only be tested after evaluating many known genotypes and determining co- segregation with phenotype. The main objective of this study was to determine if these RAPD markers can be utilized as tools for marker-assisted selection (MAS) in diverse melon cultigens, and, secondly, to compare the accuracy of these RAPD markers with those of their converted RFLP and CAPS markers.

\section{Materials and Methods}

Germplasm. Eighty-nine melon genotypes (Table 1), including parental lines (Group A, B), cultigens (Group C, D), and $\mathrm{F}_{1}$ hybrids (Group E, F), representing several melon classes from diverse locations were screened with three RAPD primers E07, G17, and 596. Crosses between 'Vedrantais' (susceptible) and PI 161375 (resistant) were made by M. Pitrat (INRA, Montfavet, France) for the $F_{1}$ generation, which was selfed for the $\mathrm{F}_{2}$ population. Individual $\mathrm{F}_{2}$ plants were selfed and $\mathrm{F}_{3}$ progenies were inoculated with Fusarium wilt. Homogeneous resistant or susceptible $\mathrm{F}_{3}$ were recorded to track the homozygous $\mathrm{F}_{2}$ plants. To confirm the linkage between the RAPD markers E07 and G17 and disease response in genotypes other than the parental line 'Vedrantais', crosses between 'Ananas Yokneam' (susceptible) and MR-1 (resistant) were made to produce an $\mathrm{F}_{2}$ population. Then the Fom-2 genotypes of $\mathrm{F}_{2}$ individuals were determined by scoring both RFLP and CAPS markers (Zheng et al., 1999) to make bulked DNA pools for bulked segregant analysis. In addition, 17 selfed families (Table 2) from a backcross program $\left(\mathrm{BC}_{1} \mathrm{~S}_{1}\right)$ using breeding line MD8654 as a resistance source, were also scored. Seeds for the $\mathrm{BC}_{1} \mathrm{~S}_{1}$ families were provided by B. Moraghan (Asgrow Seed Co., San Joaquin Breeding Station, Arvin, Calif.). Pedigree information is proprietary.

Fungal culture, host inoculation, disease scoring for Fusarium wilt. The disease phenotypes of melon cultigens and $\mathrm{F}_{1}$ hybrids (Table 1) were determined as follows. The evaluation of Fusarium resistance of the parental lines 'Vedrantais' $x$ PI 161375, and their $F_{2}$ and $F_{3}$ progenies, as well as of the resistant cultigens listed in Table 1 (except MR-1 and 'Vine Peach'), was conducted by M. Pitrat by using a Fusarium isolate FOM 26 (race 1). The mycelia were cultured on potato dextrose agar (PDA) plates and conidial suspensions were used to roots dip as described by Risser and Mas (1965). Roots of 20 seedlings of each $\mathrm{F}_{3}$ family were dipped in a conidial suspension before transplanting to sand. Susceptible plants died 2 weeks after inoculation, whereas resistant ones remained green. The disease phenotypes of MR-1 and 'Vine Peach' and all of the susceptible cultigens were cited from published screening experiments (Baudracco-Arnas and Pitrat, 1996; Wechter et al., 1995; Zink, 1991; 1992; Zink and Gubler, 1985; Zink and Thomas, 1990). The disease phenotypes for the $F_{1}$ hybrids were determined by several seed companies or cited from seed catalog descriptions (Asgrow Seed Co.; Harris Moran, San Juan Bautista, Calif.; Sakata Seed America, Lehigh, 
Table 1. Presence of RAPD markers in diverse melon (Cucumis melo L.) cultigens with different reactions to Fusarium oxysporium f. sp. melonis races 0 and 1 .

\begin{tabular}{|c|c|c|c|c|c|}
\hline \multirow[b]{2}{*}{ Cultigen $/ \mathrm{F}_{1}$ hybrid } & \multirow[b]{2}{*}{ Source } & \multicolumn{4}{|c|}{ RAPD marker } \\
\hline & & $\begin{array}{c}\mathrm{E} 07 \\
(1.25 \mathrm{~kb})^{\mathrm{z}}\end{array}$ & $\begin{array}{c}\mathrm{G} 17 \\
(1.05 \mathrm{~kb})^{\mathrm{z}}\end{array}$ & $\begin{array}{c}596 \\
(1.6 \mathrm{~kb})^{\mathrm{y}}\end{array}$ & $\begin{array}{c}596 \\
(1.55 \mathrm{~kb})^{\mathrm{y}} \\
\end{array}$ \\
\hline \multicolumn{6}{|c|}{ Group A: Resistance parental lines } \\
\hline PI 161375 & Korea & - & - & - & + \\
\hline MR-1/PI 124111.I & India & - & - & + & + \\
\hline \multicolumn{6}{|c|}{ Group B: Susceptible parental lines } \\
\hline Vedrantais & France & + & + & - & - \\
\hline Ananas Yokneam & Hollar & + & + & - & - \\
\hline \multicolumn{6}{|c|}{ Group C: Resistant cultigens } \\
\hline Aodaisimouri & Japan & - & - & - & - \\
\hline Charentais Fom-2 & France & - & - & - & + \\
\hline Chenggam & Korea & - & - & - & + \\
\hline CM 17187/PI 446928 & Israel & - & - & - & + \\
\hline CM 17188 & Israel & - & - & - & - \\
\hline Freeman's cucumber & Japan & - & - & - & + \\
\hline Ginsen Makuwa & Japan & - & - & - & + \\
\hline Isabelle & France & - & - & - & + \\
\hline K 2005 & China & - & - & - & + \\
\hline Kanro Makuwa & Japan & - & - & - & + \\
\hline Kogane 9 Go Makuwa & Japan & - & - & - & + \\
\hline Kogane Sennari Makuwa & Japan & - & - & - & + \\
\hline LJ 34340 & TW Whitaker & + & + & - & + \\
\hline LJ 90279/ PI 157083 & China & - & - & - & + \\
\hline LJ 90389 & TW Whitaker & - & - & - & + \\
\hline Meshed & Iran & - & - & - & - \\
\hline Miel Blanc & China & - & - & - & + \\
\hline Nanbukin & China & - & - & - & - \\
\hline Nyumelon & Japan & - & - & - & + \\
\hline Ogon 9 & Japan & - & - & - & - \\
\hline Ouzbeque 1 & Japan & - & - & - & - \\
\hline Perlicha 1.5 & Guadeloupe & - & - & - & + \\
\hline Persia 202 & Iran & + & + & - & - \\
\hline PI 157084 & China & - & - & - & - \\
\hline PI 125915 & Afghanistan & - & - & - & - \\
\hline PI 164723 & India & - & - & - & + \\
\hline PI 223637 & Iran & - & - & - & - \\
\hline Samarcande & USSR & - & - & - & - \\
\hline Semosouri Varamin & Iran & - & - & - & - \\
\hline Shiroubi Okyama & Japan & - & - & - & + \\
\hline Showa Kogane Nashi Makuwa & Japan & - & - & - & + \\
\hline Sisi & Iran & $? /+^{x}$ & - & - & - \\
\hline Tokio Mammuth & Japan & - & - & - & - \\
\hline Vine Peach & Hollar & - & + & + & + \\
\hline \multicolumn{6}{|c|}{ Group D: Susceptible cultigens } \\
\hline Casaba Golden Beauty & Hollar & + & - & - & - \\
\hline Charentais $\mathrm{T}$ & F. Zink & + & + & - & - \\
\hline Crenshaw & Hollar & + & - & - & - \\
\hline D21 1005 & E. Cox & + & - & - & - \\
\hline D21 1014 & E. Cox & + & + & - & - \\
\hline Delicious 51 & Hollar & + & + & - & - \\
\hline Doublon & F. Zink & + & + & - & - \\
\hline Dulce & R.T. Correa & + & + & - & - \\
\hline Honey Dew Green Flesh & Hollar & + & + & - & - \\
\hline Honey Dew Orange Flesh & Hollar & + & + & - & - \\
\hline Iroquois & Hollar & + & - & - & - \\
\hline Israel Ogen & Wilhite & + & - & - & - \\
\hline Marygold & Hollar & + & - & - & - \\
\hline Mondo & Nunhems & + & - & - & $?$ \\
\hline Perlita & R.T. Corea & + & + & - & - \\
\hline Perlita 45/21 & R.T. Correa & + & + & - & - \\
\hline Persian & Hollar & + & + & - & - \\
\hline Santa Clause & Hollar & + & + & - & $?$ \\
\hline TAM Dew Improved & R.T. Correa & + & - & - & - \\
\hline TAM Mayan Sweet & R.T. Correa & + & $? /-$ & - & - \\
\hline TAM Perlita 45 & R.T. Correa & + & + & - & - \\
\hline TAM Sun & B. Scully & + & + & - & - \\
\hline TAM Yellow Canary & R.T. Correa & + & $? /-$ & - & - \\
\hline TAM Uvalde & R.T. Correa & + & $? /-$ & - & - \\
\hline Topmark & Hollar & + & + & - & - \\
\hline UC Topmark & UC Davis & + & + & - & - \\
\hline
\end{tabular}

Table 2. Co-segregation of RAPD markers in $\mathrm{BC}_{1} \mathrm{~S}_{1}$ families with different reactions to Fusarium oxysporium $\mathrm{f}$. sp. melonis races 0 and 1.

\begin{tabular}{|c|c|c|c|}
\hline \multirow[b]{2}{*}{$\begin{array}{l}\mathrm{BC}_{1} \mathrm{~S}_{1} \\
\text { family }\end{array}$} & \multirow[b]{2}{*}{$\begin{array}{c}\text { Infected } \\
\text { plants }(\%)^{\mathrm{z}}\end{array}$} & \multicolumn{2}{|c|}{ Marker } \\
\hline & & $\begin{array}{c}\mathrm{E} 07 \\
(1.25 \mathrm{~kb})^{\mathrm{y}}\end{array}$ & $\begin{array}{c}\mathrm{G} 17 \\
(1.05 \mathrm{~kb})^{\mathrm{y}}\end{array}$ \\
\hline 5 & 0 & - & - \\
\hline 14 & 0 & - & - \\
\hline 25 & 0 & - & - \\
\hline 29 & 0 & - & - \\
\hline 33 & 0 & - & - \\
\hline 34 & 0 & - & - \\
\hline 35 & 0 & - & - \\
\hline 36 & 0 & - & - \\
\hline 38 & 0 & - & - \\
\hline 39 & 0 & - & - \\
\hline 40 & 0 & - & - \\
\hline 37 & 6 & - & - \\
\hline 9 & 34 & + & + \\
\hline 32 & 40 & + & - \\
\hline 8 & 50 & + & + \\
\hline 7 & 67 & + & + \\
\hline 24 & 94 & + & - \\
\hline 11 & 100 & + & + \\
\hline 23 & 100 & + & - \\
\hline
\end{tabular}

Percentage of infected plants among the 25 individuals in a $\mathrm{BC}_{1} \mathrm{~S}_{1}$ family.

$\mathrm{y}_{+} /-=$presence/absence of the susceptible-linked marker band, E07-1.25 kb and G17-1.05 kb.

Fla.; Nunhems Seeds, Haelen, The Netherlands). Disease reactions of the $\mathrm{BC}_{1} \mathrm{~S}_{1}$ families were determined by B. Moraghan. He used the seedling tray root-dipping procedure described by Zink (1992). For the $\mathrm{BC}_{1} \mathrm{~S}_{1}$ families (Table 2 ), the disease reactions were the percentage of infected seedlings present in a family of 25 individuals.

Genomic DNA. Healthy leaves were harvested from melon seedlings grown in the greenhouse at the three- to five-leaf stage. Genomic DNAs were extracted from either freshly harvested leaves frozen in liquid nitrogen, or from dehydrated leaves, according to Baudracco-Arnas (1995). The DNA samples of the $17 \mathrm{BC}_{1} \mathrm{~S}_{1}$ families (Table 2) were each extracted from bulked leaf tissue from 25 plants. If a family segregated for Fom-2, then the DNA sample from the pooled individuals of the corresponding segregating family was heterozygous. DNA quantification and qualification were determined by a UV-VIS scanning spectrophotometer (UV2101PC; Shimadzu Scientific Instrument, Md.). All DNA samples had $\mathrm{A}_{260}: \mathrm{A}_{280}$ ratios above 1.8. DNA concentrations of $10 \mathrm{ng} \cdot \mu \mathrm{L}^{-1}$ were prepared for all samples for use in PCR and the rest were stored in $-80^{\circ} \mathrm{C}$.

Bulk segregant analysis. Bulk DNAs from both crosses 'Ananas Yokneum' $\mathrm{X}$ 'MR-1' and 'Vedrantais' $x$ PI 161375 were prepared according to Michelmore et al. (1991). Homozygous resistant bulk DNAs (referred to as resistant bulks) were prepared by mixing equal amounts of DNA from 10 individual homozygous resistant $\mathrm{F}_{2}$ plants. Likewise, heterozygous resistant bulk DNAs contained an equal amount of DNA from 10 individual homozygous resistant $\mathrm{F}_{2}$ and 20 individual heterozygous resistant $\mathrm{F}_{2}$ plants. The susceptible bulk DNAs contained an equal amount of $10 \mathrm{~F}_{2}$ susceptible individual 
Table 1. Continued.

\begin{tabular}{|c|c|c|c|c|c|}
\hline \multirow[b]{2}{*}{ Cultigen $/ \mathrm{F}_{1}$ hybrid } & \multirow[b]{2}{*}{ Source } & \multicolumn{4}{|c|}{ RAPD marker } \\
\hline & & $\begin{array}{c}\text { E07 } \\
(1.25 \mathrm{~kb})^{\mathrm{z}}\end{array}$ & $\begin{array}{c}\mathrm{G} 17 \\
(1.05 \mathrm{~kb})^{\mathrm{z}} \\
\end{array}$ & $\begin{array}{c}596 \\
(1.6 \mathrm{~kb})^{\mathrm{y}} \\
\end{array}$ & $\begin{array}{c}596 \\
(1.55 \mathrm{~kb})^{\mathrm{y}} \\
\end{array}$ \\
\hline \multicolumn{6}{|c|}{ Group E: Resistant $F_{1}$ hybrids } \\
\hline Accent & Nunhems & - & $? /-$ & - & - \\
\hline Aril & Nunhems & + & - & - & - \\
\hline Corin & Nunhems & + & + & - & - \\
\hline Daimiel & Nunhems & + & - & - & + \\
\hline Desio & Nunhems & - & - & + & - \\
\hline Galia & Nunhems & - & - & - & - \\
\hline Lutina & Nunhems & + & - & - & - \\
\hline Pandor & Nunhems & + & - & - & - \\
\hline Preco & Nunhems & + & + & - & - \\
\hline Solo & Nunhems & + & - & - & - \\
\hline Toledo & Nunhems & + & - & - & - \\
\hline Viva & Nunhems & - & - & - & - \\
\hline \multicolumn{6}{|c|}{ Group F: Susceptible $F_{l}$ hybrids } \\
\hline Athena & Rogers NK & + & + & - & - \\
\hline Castella & Nunhems & + & + & - & - \\
\hline Cruiser & Harris Moran & + & + & - & - \\
\hline Delada & Nunhems & + & - & - & - \\
\hline Deltex & Nunhems & + & + & - & - \\
\hline Fiola & Nunhems & + & + & - & - \\
\hline Honeybrew & Sakata & + & + & - & - \\
\hline Laguna & Asgrow & + & + & - & - \\
\hline Mission & Asgrow & + & + & - & - \\
\hline Mondo & Nunhems & + & - & - & $?$ \\
\hline Morning Ice & Harris Moran & + & + & - & - \\
\hline Primo & Rogers NK & + & + & - & - \\
\hline Rocky Sweet & Hollar & + & + & - & - \\
\hline Spice & Hollar & + & + & - & - \\
\hline
\end{tabular}

${ }^{\mathrm{z}}$ Markers linked to susceptibility.

${ }^{\mathrm{y}}$ Markers linked to resistance.

$\mathrm{x} ? /+$ and ?/- denotes that RAPD results were difficult to score for the reasons indicated in text but were later clarified by the results of Southern hybridization.

DNA samples. For the bulk DNAs from the $\mathrm{F}_{2}$ population of the cross between 'Vedrantais' x PI 161375, the resistant bulk contained equal amounts of 46 homozygous resistant DNA samples, and the susceptible bulk DNAs contained equal amounts of 47 homozygous susceptible DNA samples.

Polymerase chain reaction $(P C R)$. All PCR conditions were optimized and modified from protocols of Baudracco-Arnas and Pitrat (1996) and Wechter et al. (1995) by using a different source of Taq polymerase (Promega Corp., Madison, Wis.). Concentrations of all DNA samples were diluted to 10 $\mathrm{ng} \cdot \mu \mathrm{L}^{-1}$. All PCR amplifications were carried out in $25-\mu \mathrm{L}$ reaction volumes in $600-\mu \mathrm{L}$ tubes. Each reaction mixture contained 13.38 $\mu \mathrm{L}$ of $\mathrm{ddH}_{2} \mathrm{O}$ (Sigma, St. Louis), $2.5 \mu \mathrm{L}$ of 10 $\times$ buffer $\mathrm{A}, 2.5 \mu \mathrm{L}$ of $25 \mathrm{~mm} \mathrm{MgCl}, 0.13 \mu \mathrm{L}$ of Taq polymerase, $2.0 \mu \mathrm{L}$ of $2.5 \mathrm{~mm}$ dNTP (New England Biolabs, Bevery, Mass.), 2.5 $\mathrm{mL}$ of $6 \mathrm{ng} \cdot \mu \mathrm{L}^{-1}$ primers for E07 and $\mathrm{G} 17$ or $30 \mathrm{ng} \cdot \mu \mathrm{L}^{-1}$ for primer 596 , and $2.0 \mathrm{~mL} \mathrm{DNA}$ $\left(10 \mathrm{ng} \cdot \mu \mathrm{L}^{-1}\right)$. Two drops of mineral oil were added to the top of each tube. All three primers were synthesized by New England Biolabs. The PCRs were run on a DNA Thermal Cycler 480 (Perkin-Elmer, Norwalk, Conn.). The PCR cycle parameters were 3 min at $93{ }^{\circ} \mathrm{C}$, followed by 46 cycles of $1 \mathrm{~min}$ at $93{ }^{\circ} \mathrm{C}, 1 \mathrm{~min}$ at $40^{\circ} \mathrm{C}, 2 \mathrm{~min}$ at $72^{\circ} \mathrm{C}$, and the final $10 \mathrm{~min}$ at $72^{\circ} \mathrm{C}$. The products were separated by electrophoresis at 3-5 V/cm through a $1.2 \%$ agarose gel and stained with
$0.5 \mu \mathrm{g} \cdot \mu \mathrm{L}^{-1}$ ethidium bromide before being photographed under UV light. Gel pictures were then scored for the polymorphic DNA bands. For those scores that did not match the disease phenotype, up to three additional PCR runs were conducted to confirm the results. For all negatives, the whole PCR profile was compared with the positive ones to eliminate the possibility that the negative was the result of PCR failure.

Cloning the RAPD targetfragments. First, the RAPD fragments, E07-1.25 and G171.05 , linked to susceptible 'Vedrantais' (Baudracco-Arnas and Pitrat, 1996), were amplified, and the target PCR bands were cut from the agarose gel. The DNA fragments were resuspended in $\mathrm{dH}_{2} \mathrm{O}$ using the protocols described by either Geneclean ${ }^{\circledR}$, II Kit or Spin Module from Bio 101 (1070 Joshua Way, Vista, Calif.). Either the Original TA Cloning ${ }^{\circledR}$ Kit (Invitrogen Corp. San Diego) or Promega pGEM ${ }^{\circledR}$-T Easy Vector Systems (Promega Corp.) were used to clone the PCR fragments following the manufacturer's ligation and transformation protocols. To identify clones that contained the right insert, four to six putative clones were chosen and cultured in LB medium plates (1\% tryptone, $0.5 \%$ yeast extract, $1 \% \mathrm{NaCl}, 1.5 \%$ agar, $\mathrm{pH}$ 7.0). The plasmids were isolated and digested with EcoR I to check for the inserts by gel electrophoresis. Clone(s) containing the inserts that corresponded to $\mathrm{PCR}$ products were saved for use in preparating DNA probes.
Southern hybridization. To verify the sequence homology of RAPD marker bands amplified from different genotypes, DNA gel blotting analyses were carried out. The PCR products were separated by electrophoresis in $1.0 \%$ agarose (Sigma) gels at $3 \mathrm{~V} / \mathrm{cm}$ for $4 \mathrm{~h}$ in TAE buffer. After electrophoresis, gels were treated with 10 volumes of $0.25 \mathrm{~N} \mathrm{HCl}$ for 10 $15 \mathrm{~min}$ and then with $0.4 \mathrm{M} \mathrm{NaOH}$ for $20 \mathrm{~min}$ on a shaker. The DNA was then blotted onto Hybond- $\mathrm{N}^{+}$membrane (Amersham Life Science, Arlington Heights, Ill.) for $2-3 \mathrm{~h}$ in an "alkali-downward" capillary blotting procedure similar to that used by Koetsier et al. (1993).

Clone-derived PCR fragments of E07 and G17 originating from PCR amplification of DNA from the susceptible parental line 'Vedrantais' were used as hybridization probes. To purify the inserts (i.e., fragments E07 and G17) used as probes, the plasmids containing corresponding inserts were digested with EcoR I. After electrophoresis of the digestion products, the corresponding bands were cut out from the agarose gel and were purified and resuspended in $\mathrm{dH}_{2} \mathrm{O}$ as described earlier. A nonradioactive labeling and detection system (Amersham Life Science) was used in probe labelings, hybridizations, and signal generations and detections following an optimized protocol of Zheng and Wolff (1999). The blots were exposed on Hyperfilm-MP for 5-60 min before developing the films. The hybridization signals were then scored as positives or negatives.

\section{Results}

Conservation of RAPD markers in diverse genotypes. Scores of the four RAPD markers in diverse melon cultigens were listed in Table 1 . The RAPD markers of $1.25-\mathrm{kb}$ and 1.05 -kb fragments resulting from primers E07 and G17 were not only confirmed in the susceptible parent 'Vedrantais' (Baudracco-Arnas and Pitrat, 1996), but were also found in other susceptible cultigens. (Fig. 1A and B). Similarly, a polymorphic fragment of $1.6 \mathrm{~kb}$ linked to resistance in MR-1 (Wechter et al., 1995) was confirmed by using primer 596 (Fig. 1C). It was also detected in resistant lines 'Desio' and 'Vine Peach'. A 1.55-kb polymorphic fragment resulting from primer 596 was found to associate with resistance. Among the 11 cultigens in which phenotype did not match with RAPD-E07 scores, eight were resistant $F_{1}$ hybrids ('Aril', 'Corin', 'Daimiel', 'Lutina', 'Pandor', 'Preco', 'Solo', and 'Toledo') that had the susceptible-linked E07-1.25-kb RAPD marker. Among the other three lines (LJ34340, Persia 202, and 'Sisi'), LJ 34340 was later found to segregate for resistance (M. Pitrat, personal communication.). For primer G17, five out of 14 mismatched genotypes, two $F_{1}$ hybrids ('Corin' and 'Preco') and three lines (LJ 34340, Persia 202, and 'Vine Peach'), were resistant phenotypically but were scored as susceptible for the marker, i.e., showed a $1.05-\mathrm{kb}$ fragment. The other nine genotypes, including one $F_{1}$ hybrid ('Delada') and eight lines ('Casaba Golden Beauty', 'Crenshaw', 

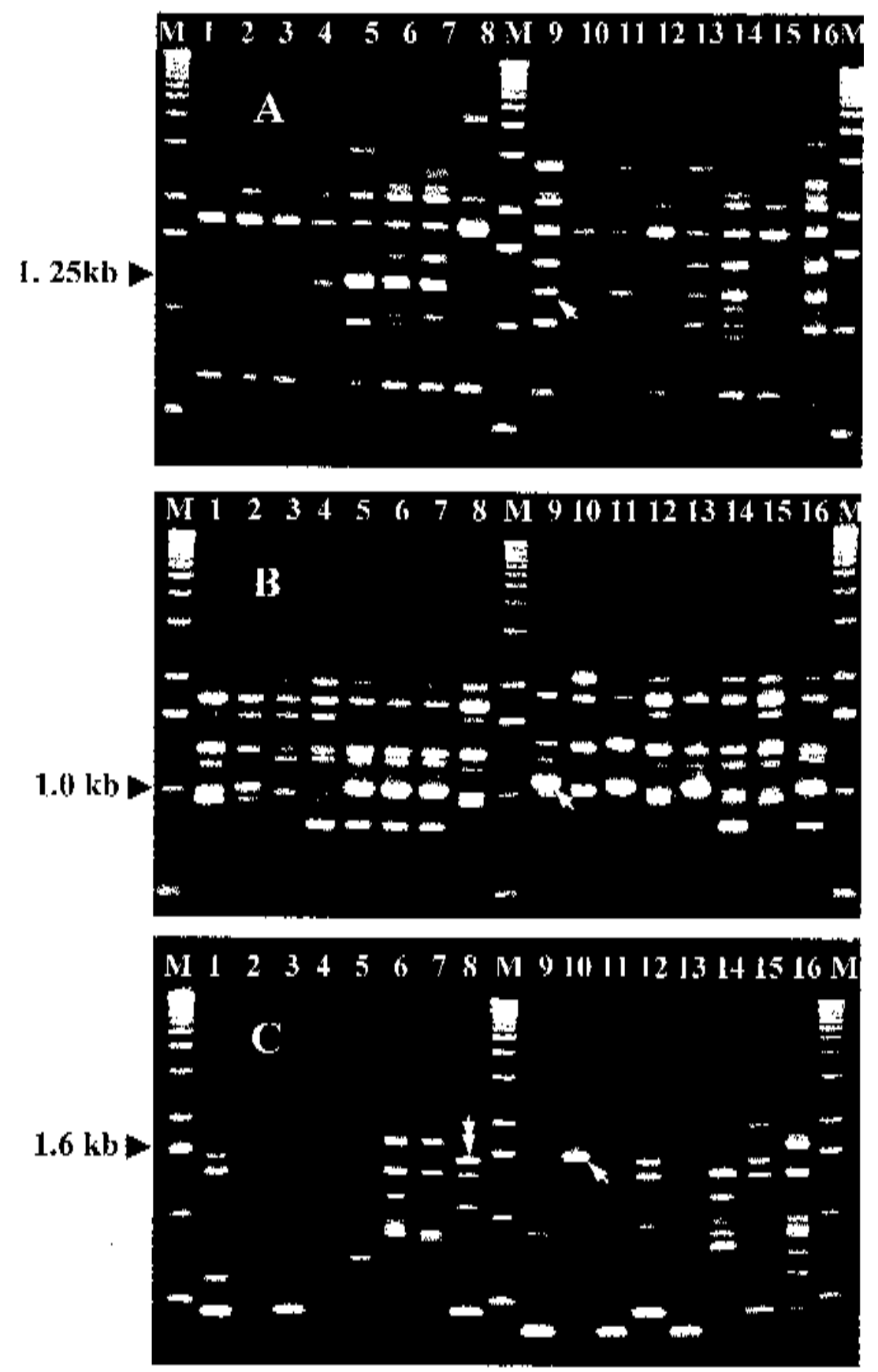

Fig. 1. Ethidium bromide-stained gel of polymerase chain reaction (PCR) amplified products using decamer primer E07 (panel A), G17 (panel B), and 596 (panel C) and genomic DNAs of melon lines differing in resistance to Fusarium wilt caused by Fusarium oxysporium f. sp. melonis races 0 and 1. Lanes 1, 2, 3, 4, 8, 10, 12, and 15 are resistant genotypes 'Charentais Fom-2', LJ 90279, PI 446928, 'Sisi', PI 161375, MR-1, 'Isabelle', and 'Freeman's Cucumber', respectively. Lanes 5, 6, 7, 9, 11, 13, 14, and 16 are susceptible genotypes 'TAMUvalde', 'Cruiser', 'Honey Dew Orange Flesh', 'Vedrantais', 'Iroquois', 'Delicious 51', 'Crenshaw', and 'Perlita', respectively. The single arrow indicates the 1.25$\mathrm{kb}$ (panel A), 1.05-kb (panel B), and 1.6-kb (panel C) polymorphic marker band. The double arrow indicates the $1.55-\mathrm{kb}$ fragment (panel C) associated with resistance when primer 596 was used. $\mathrm{M}$ is a 1-kb DNA ladder from Gibco BRL, Life Technologies, Gaithersburg, Md.

D21 1005, 'Iroquois', 'Israel Ogen', 'Marygold', 'Mondo', and 'TAM Dew Improved'), were susceptible phenotypically but were scored as resistant for the G17 RAPD marker, i.e., absence of a 1.05-kb fragment. Four genotypes, including three susceptible cultivars ('TAM Mayan Sweet', 'TAM Yellow Canary', and 'TAMUvalde') and one resistant $\mathrm{F}_{1}$ hybrid ('Accent'), were difficult to score because they showed a $1.05-\mathrm{kb}$ fragment that was not as intense as those observed in the other susceptible lines. These accessions were later verified by Southern hybridization. For primers E07 and G17, most of the mismatching between marker genotype and disease phenotype could be accounted for by the known hybridism because of the dominance of the RAPD marker. Only two lines (LJ 34340 and Persia 202) were mismatched for both markers. The fragment linked to susceptibility from primer E07 (1.25-kb) and G17 $(1.05-\mathrm{kb})$ correctly matched the phenotype in $78(88 \%)$ and $72(81 \%)$ of the 89 cultigens, respectively (Table 3 ). When combining E07 and G17 scores (at least one matching), the marker genotype(s) matched the disease reaction phenotypes in $95 \%$ of the melon lines and hybrids tested (Table 3). For primer 596, the newly identified 1.55 $\mathrm{kb}$ fragment was found in 22 out of $36(61 \%)$ of the resistant lines (Table 1, Group C) but in none of the susceptible lines (Table 1, Group D), with a 70\% match with phenotype overall (Table 3 ).

Verification of RAPD score results by DNA gel blotting analysis. PCR products with the same molecular size do not necessarily have the same origin and/or sequence when amplified from different genotypes. DNA gel blotting analyses were thus conducted to verify the RAPD scores in diverse melon genotypes. Southern hybridization results confirmed the RAPD scores for E07 marker on all melon cultigens and $F_{1}$ hybrids (Fig. 2). All melon cultigens and $F_{1}$ hybrids that showed E07-1.25-kb RAPD marker fragments and scored as positive (Fig. 1A; Table 1) produced a positive hybridization signal when probed with the clone-derived E07-1.25-kb fragment from the susceptible line 'Vedrantais'. The Southern hybridization results not only verified the RAPD scores for G17 marker, but also corrected one error of RAPD score in D211005. For this phenotypically susceptible genotype, it was scored as resistant by RAPD marker scoring because of the absence of the susceptible-linked G17-1.05-kb fragment. However, the Southern hybridization results showed a positive hybridization signal and was thus relabeled as susceptible.

Confirmation of RAPD score results by bulk segregant analysis. The 1.25-kb E07 fragments were amplified from both $\mathrm{F}_{2}$ homozygous susceptible and heterozygous resistant bulks from both crosses, either between 'Vedrantais' $x$ PI 161375 or 'Ananas Yokneum' x MR-1 (Fig. 3A). However, a much less intensive $1.25-\mathrm{kb}$ fragment was detectable sometimes from homozygous resistant bulks compared with the fragments amplified from the $\mathrm{F}_{2}$ homozygous susceptible and heterozygous resistant bulks. Primer G17 amplified a 1.05$\mathrm{kb}$ fragment only from the $\mathrm{F}_{2}$ susceptible and heterozygous resistant bulks from both crosses, but not from the homozygous resistant bulks (Fig. 3 B).

Score of RAPD markers E07 and G17 in a segregating backcross population. Although information about parental lines (from a private seed company) was not available, both RAPD markers predicted the resistance phenotype of the backcross families (Table 2). For the susceptible backcross families that contained different percentages of susceptible individuals in each segregating population, E07-RAPD scored more precisely than did G17-RAPD. The former had only one mismatch that 
Table 3. Prediction accuracy of three RAPD markers linked to the Fom-2 gene conferring resistance to Fusarium oxysporum $\mathrm{f}$. $\mathrm{sp}$. melonis races 0 and 1 in diverse melon cultigens. ${ }^{2}$

\begin{tabular}{lccccc}
\hline \hline & \multicolumn{2}{c}{ Match } & & \multicolumn{2}{c}{ Mismatch } \\
\cline { 2 - 3 } \cline { 5 - 6 } RAPD marker & Count & $\%$ & & Count & $\%$ \\
\hline E07 & 78 & 88 & & 11 & 12 \\
G17 & 72 & 81 & & 17 & 19 \\
596 & 62 & 70 & & 27 & 30 \\
E07/G17y & 85 & 95 & & 4 & 5 \\
\hline
\end{tabular}

${ }^{2}$ PrimerE07 and G17 are susceptible-linked markers, primer 596 is a resistant-associated marker of 1.55 $\mathrm{kb}$. The genotypes of the three RAPD markers were fragments of $1.25,1.05$, and $1.55 \mathrm{~kb}$, respectively. ${ }^{y} \mathrm{E} 07 / \mathrm{G} 17$ means the combined data from the two markers, i.e., one match with either primer was counted as correctly predicting phenotype. Disease reactions of melon lines and hybrids were tested as described in text.

contained $6 \%$ of susceptible individuals in a segregating population of 25 plants.

\section{Discussion}

Our data present a comprehensive test and show the utility of dominant- and susceptiblelinked RAPD markers to Fusarium wilt in diverse melon cultigens. RAPD markers E07 and G17 had a high degree of conservation among the melon cultigens and $F_{1}$ hybrids from diverse locations and origins. The validity of the RAPD scores in diverse melon cultigens was confirmed by Southern hybridization (Thormann et al., 1994), in which only the RAPD fragments with sequences identical with or highly similar to that of the probe (from the original parental line) resulted in positive hybridization. Identified originally from a segregating population of 'Vedrantais' $x$ PI 161375, the validity of the RAPD markers E07 and G17 were further substantiated by bulked segregant analysis in an additional selected segregation population derived from 'Ananas Yokneam' x MR-1. A linkage must exist in other melon cultigens that had positive scores in both RAPD and Southern hybridization.

All mismatches for E07 RAPD were derived from phenotypically resistant lines that were scored as susceptible, i.e., showing the susceptible-linked $1.25-\mathrm{kb}$ fragment. The majority of these were $F_{1}$ resistant hybrids. If one parent carried Fom-2, then the $\mathrm{F}_{1}$ was heterozygous and disease-resistant. Theoretically, the susceptible-linked marker RAPD E07-1.25 kb would be detected in a heterozygous plant, while the phenotype would be resistant. Three other genotypes (LJ 34340, Persia 202, and 'Vine Peach') that were mismatched with the E07 RAPD marker were not hybrids but could be heterozygous for Fom-2 gene because of recombination. Indeed, one of the genotypes (LJ 34340) was later identified to be segregant for Fusarium wilt resistance. The primer E07 was $1.6 \pm 0.9 \mathrm{~cm}$ away from the resistance gene Fom-2 (BaudraccoArnas and Pitrat, 1995; Pitrat, 1991), which would result in a $2 \%$ to $5 \%$ recombination frequency. Based on this map distance, we

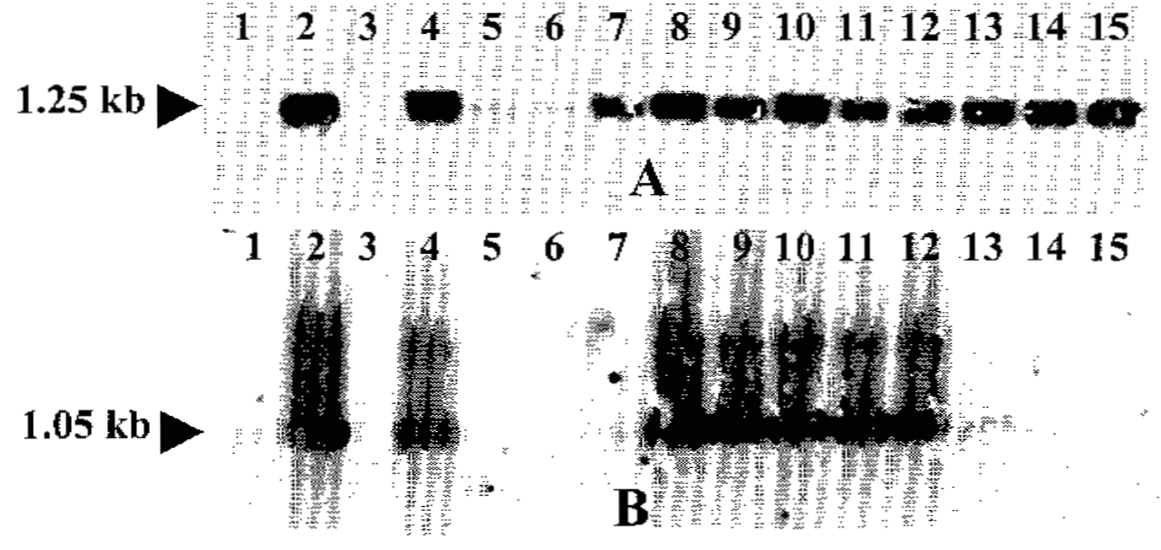

Fig. 2. Southern hybridization analysis of polymerase chain reaction (PCR) amplified products from genomic DNA of selected melon genotypes. Panels A and $\mathbf{B}$ were probed with clone-derived PCR fragments of E07-1.25 kb and G17-1.05 kb, respectively, which were originated from the susceptible parental line 'Vedrantais'. Lanes 1, 3, 5, and 6 are resistant lines of PI 161375, MR-1, 'Aodaisimoari', and 'Charentais Fom-2', respectively. Lanes 7-15 are 'Vedrantais', 'Ananas Yokneam', 'Casaba Golden Beauty', 'Charantais T', 'Delicious 51', 'Honey Dew Green Flesh', 'Honey Dew Orange Flesh', 'Iroqouis', 'TAM Mayan Sweet', 'TAM Yellow Canary', and 'TAM Uvalde', respectively.
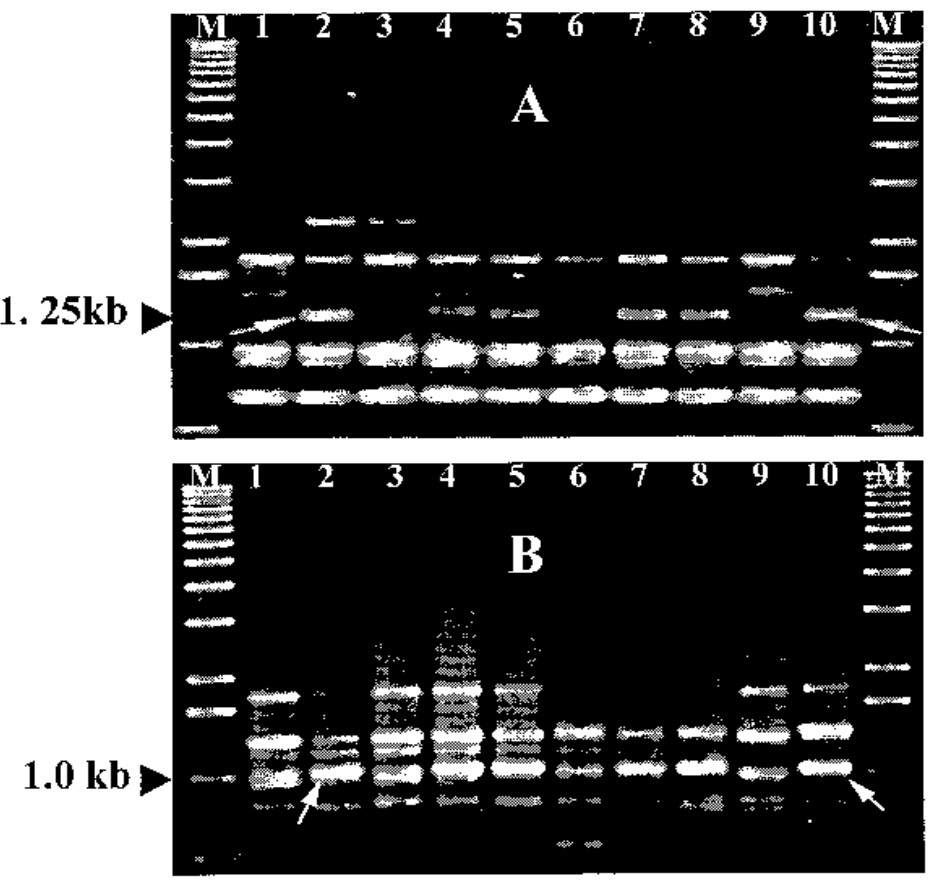

Fig. 3. Ethidium bromide-stained gel of polymerase chain reaction (PCR) amplified products using decamer primer E07 (panel A) and G17 (panel B) on bulked DNAs of $F_{2}$ populations from crosses 'Vedrantais' X PI 161375 and 'Ananas Yokneam' x MR-1. Lane 1 is PI 161375, lane 2 'Vedrantais'. Lanes 3, 4, and 5 are resistant bulked DNA, heterozygous bulked DNA, and susceptible bulked DNA, respectively, from 'Vedrantais' $x$ PI $161375 \mathrm{~F}_{2}$ individuals. Lanes 6, 7, and 8 are resistant bulked DNA, heterozygous bulked DNA, and susceptible bulked DNA, respectively, from 'Ananas Yokneam' $\mathrm{x}$ MR-1 $\mathrm{F}_{2}$ individuals. Lane 9 is MR-1 and lane 10 'Ananas Yokneam'. M is a 1-kb DNA ladder from Gibco BRL, Life Technologies, Gaithersburg, Md.

would expect $\approx 2 \%$ to $5 \%$ of the mismatches to be due to recombination events. The fact that two different genes (Fom-2 and Fom-3) present in different cultigens of melon and control resistance to the same race of $F$. oxysporum $\mathrm{f}$. sp. melonis (Zink and Gubler, 1985) may also contribute to the mismatch. Thus, the susceptible linked primer E07 was adequate and suggestive of its potential. Primer G17 was 4.5 $\pm 1.5 \mathrm{~cm}$ from Fom-2 (Baudracco-Arnas and
Pitrat, 1996; Pitrat, 1991), and would produce a $6 \%$ to $12 \%$ recombination frequency. As described above for E07, the RAPD marker G17 also worked very well in our test.

Our data suggest that problems associated with PCR failure could be eliminated by comparing the whole PCR profile between the susceptible and resistant samples in the gel picture, instead of the target fragment only. However, the fact that RAPD-PCRs are sub- 
jected to different sources or batches of Taq polymerases, tissue ages, PCR conditions, and even different PCR runs (Staub et al., 1996) was observed in this study. Ironically, for RAPD primer 596, an additional polymorphic fragment of $1.55 \mathrm{~kb}$ associated with resistance was identified by using a Taq polymerase differed from the original investigators who reported a 1.60-kb RAPD linked to resistance in melon line MR-1 (Wechter et al., 1995). The newly identified RAPD marker $(1.55 \mathrm{~kb})$ was found in 23 of the $36(64 \%)$ resistant melon cultigens, but in none of the susceptible cultigens tested (Zheng et al., unpublished data). Primer E07 produced a $1.25-\mathrm{kb}$ marker band with variable intensity in some cultigens or $\mathrm{BC}_{1} \mathrm{~S}_{1}$ families that had DNA pooled from varying percentages of diseased plants in the population. The reduced intensity (varied in degrees) of $1.25 \mathrm{~kb}$ marker band was not due to PCR partial failure, because other bands in the PCR profiles were about the same as those with the typical E07-1.25-kb fragment. The multiple copies of the E07 fragment located across the melon genome, as revealed by genomic Southern hybridization (Zheng et al., 1999), may be responsible for this. The RAPD marker that resulted from primer G17 is a $1.05-\mathrm{kb}$ fragment. We observed two other bands with sizes at $\approx 1.0$ and $0.95 \mathrm{~kb}$. The presence of multiple bands of similar size makes scoring the marker band difficult.

Among the three markers tested in 89 melon cultigens, RAPD-E07 was the most accurate $(88 \%)$ in predicting disease phenotype, with RAPD-G17 (81\%) intermediate and RAPD$596(6 \%)$ third. The 1.6-kb RAPD marker amplified by primer 956 was detected in MR-1 (Wechter et al., 1995) and two other lines ('Vine Peach' and 'Desio'). The susceptible-linked markers (E07 and G17) were more conserved over genotypes than was the resistant-linked marker (956). The association of the 1.55-kb RAPD fragment with Fusarium wilt resistance in diverse melon cultigens will be further investigated. The RAPD markers E07 and G17 were satisfactory because of more rapid and cost efficient than were the CAPS and RFLP markers. Our results will impact melon breeding programs that focus on the introgression of resistance genes.

\section{Literature Cited}

Baudracco-Arnas, S. 1995. A simple and inexpensive method for DNA extraction from Cucumis melo L. Cucurbit Genet. Coop. Rpt. 18:50-51.

Baudracco-Arnas, S. and M. Pitrat. 1996. A genetic map of melon (Cucumis melo L.) with RFLP, RAPD, isozyme, disease resistance and morphological markers. Theor. Appl. Genet. 93:57-64.

Benoit, F. 1974. The Fusarium problem in melon growing in Belgium and the relative value of certain rootstocks. Tuinbouwerichten (Belgium) $38: 16-20$.

Chupp, C. 1930a. Fusarium wilt of muskmelon. Plant Dis. Rptr. 14:160.

Chupp, C. 1930b. Fusarium wilt of muskmelon. Plant Dis. Rptr. 81:116 (Suppl.).

Koetsier, P.A, J. Schorr, and W. Doerfler. 1993. A rapid optimized protocol for downward alkaline Southern blotting of DNA. BioTechniques 15:260-262.

Leach, J.G. 1933. A destructive Fusarium wilt of muskmelon. Phytopathology 23:554-556.

Leach, J.G. and T.M. Currence. 1938. Fusarium wilt of muskmelons in Minnesota. Minn. Agr. Expt. Sta. Tech. Bul. 129.

Leary, J.V. and W.D. Wilbur. 1976. Identification of the races of Fusarium oxysporum f. sp.melonis causing wilt of muskmelon in California. Phytopathology 66:15-16.

Michelmore, R.W., I. Paran, and R.V. Kesseli. 1991. Identification of markers linked to diseaseresistance genes by bulked segregant analysis: A rapid method to detect markers in specific genomic regions by using segregating populations. Proc. Natl. Acad. Sci. USA 88:9828-9832.

Pitrat, M. 1991. Linkage groups in Cucumis melo L. J. Hered. 82:406-411.

Quiot, J.B., I. Douine, and K. Gebre-Selassie. 1979. Fréquence des principales viroses identifiées dans une exploitation maraîchere de Sud-Est de la France. Ann. Phytopathology 11:283-290.

Risser, G. 1973. Etude de l'héredite de la résistance de melon (Cucumis melo) aux races 1 et 2 de Fusarium oxysporum f. sp. melonis. Ann. Amelior. Plantes 23:259-263.

Risser, G., Z. Banihashemi, and D.W. Davis. 1976. A proposed nomenclature of Fusarium oxysporum f. sp. melonis races and resistance genes in Cucumis melo. Phytopatholology. 66:11051106.

Risser G. and P. Mas. 1965. Mise en évidence de plusieurs races de Fusarium oxysporum f. sp. melonis. Ann. Amélior. Plantes 15:405-408.

Robinson, R.W., H.M. Munger, T.W. Whittaker, and G.W. Bohn. 1976. Genes of the Cucurbitaceae. HortScience 11:554-568.
Sherf, A.F. and A.A. Macnab. 1986. Fusarium wilt of muskmelon, p. 334-337. In: A.F. Sherf and A.A. Macnab (eds.). Vegetable diseases and their control. $2^{\text {nd }}$ ed. Wiley, New York.

Staub, J., J. Bacher, and K. Poetter. 1996. Sources of potential errors in the application of random amplified polymorphic DNAs in cucumber. HortScience 31:262-266.

Thormann C.E., M.E. Ferreira, L.E. Camargo, J.G. Tivang, and T.C. Osborn. 1994. Comparison of RFLP and RAPD markers to estimating genetic relationships within and among cruciferous species. Theor. Appl. Genet. 88:973-980.

Wechter, W.P., M.P. Whitehead, C.E. Thomas, and R.A. Dean. 1995. Identification of a randomamplified polymorphic DNA marker linked to the Fom-2 Fusarium wilt resistance gene in muskmelon MR-1. Phytopathology 85:12451249.

Williams, J.G.K., A.R. Kubelik, K.J. Livak, J.A. Rafalski, and S.V. Tingey. 1990. DNA polymorphism amplified by arbitrary primers are useful as genetic markers. Nucleic Acid Res. 18:6531-6535.

Wolff, D.W. and J. Zhou. 1996. Potential utility of RAPD markers linked to Fom-2 gene in melon (Cucumis melo L.). Cucurbit Genet. Coop. Rpt. 19:61-62.

Zheng, X.Y. and D.W. Wolff. 1999. An optimized protocol for rapid and sensitive application of Southern (Northern) hybridization by using fluorescein labeling and detecting system. Biotechnol. Tech. 13: 431-435.

Zheng, X.Y., D.W. Wolff, S. Baudracco-Arnas, and M. Pitrat. 1999. Development and utility of cleaved amplified polymorphic sequences (CAPS) and restriction fragment length polymorphisms (RFLP) linked to the Fom-2 Fusarium wilt resistance gene in melon (Cucumis melo L.). Theor. Appl. Genet. 99:453-463.

Zink, F.W. 1991. Origin of Fusarium wilt resistance in Texas AES muskmelon cultivars. Plant Dis. 75:24-26.

Zink, F.W. 1992. Genetics of resistance to Fusarium oxysporium f. sp. melonis races 0 and 2 in muskmelon cultivars 'Honeydew', 'Iroquois', and 'Delicious 51'. Plant Dis. 76:162-166.

Zink, F.W. and W.D. Gubler. 1985. Inheritance of resistance in muskmelon to Fusarium wilt. HortScience 110:600-604.

Zink, F.W. and C.E. Thomas. 1990. Genetics of resistance to Fusarium oxysporium f. sp.m melonis races 0,1 , and 2 in muskmelon line MR1. Phytopathology 80:1230-1232.

Zitter, T.A. 1997. Fusarium wilt of melon, a worldwide problem in temperate and tropical regions. Amer. Phytopathol. Soc., Southern Div. Annu. Mtg., Caribbean, 10-12 Nov. 1997. 